\title{
MANAGERIAL COMPETENCIES AMONG FIRST-LINE NEWSROOM MANAGERS AT SMALL TO MEDIUM-SIZED MAINSTREAM MEDIA ENTERPRises in South Africa
}

\author{
Elanie Steyn
}

School of Communication Studies, North-West University

TFJ Steyn

School of Entrepreneurship, Marketing and Tourism Management, North-West University

\begin{abstract}
Changes in the South African media and management environment have had distinct influences on especially small to medium-sized mainstream media enterprises (media SMEs) which often have to compete with bigger media organisations for the same news stories. Moreover, these media organisations are commonly faced with unique challenges related to human and other resources. This situation adds to the importance of effective and efficient management practices at these media sites. The management practices of first-line news managers in media SMEs are qualitatively and quantitatively evaluated in this paper by considering six managerial competencies found in general management theory. These competencies relate to communication, planning and administration, teamwork; strategic action, global awareness and self-management.
\end{abstract}

JEL M54

\section{1}

\section{Introduction}

At the turn of this century, South Africa hosted an estimated 3 million small enterprises (including informal businesses) (South Africa Yearbook, 2004/05: 173). The importance of these enterprises cannot be underestimated in terms of their contribution to the country's economy. However, as elsewhere in the world, in South Africa the failure rate of small businesses is high. Moreover, these enterprises often operate under severe restrictions related to human and other resources, which probably contributes to the high failure rate. Apart from this problem, as Venter, Van Eeden, King and Sharp (2003: 3) indicate, the majority of failures are rooted in a lack of proper management skills. That managers in small and medium-sized enterprises need proper managerial competencies is thus fairly obvious.

Since the dawn of democracy in South Africa, a number of new small- and medium-sized enterprises (SMEs) have been added to the country's mainstream media scene. Legislation on media enterprises was relaxed, and a number of new role players entered the (previously restricted) mainstream media market. Also, new entrants appeared on the media scene in attempts to diversify the media's voice. While some of these enterprises specifically aimed at and operated within a development and community media framework, others were established in the country's mainstream media context. In an environment characterised by tough competition, increased bottomline profitability and rapid technological development, it is evident that media SMEs competing with bigger counterparts face enormous challenges (see Berger, 2004; Kupe, 2004).

However, media SMEs are not the only ones who need to address the above challenges. Criticism from a variety of sources (e.g. the government, owners and audiences) also 
necessitates that the mainstream counterparts of these smaller companies also reflect on these issues (see Kupe, 2004; Berger, 2004; Von Bormann, 2004).

This situation caused the South African National Editors' Forum (SANEF) to commission two journalism-skills audits in the past five years. The first, which we can call Audit 1 , focused on levels of reporting, writing and accuracy skills among reporters (see Steyn \& De Beer, 2002, 2003, 2004), while the second, which we will call Audit 2, investigated the importance and implementation of managerial competencies among first-line newsroom managers (see Steyn, De Beer \& Steyn, 2005a). ${ }^{1}$ This article draws on Audit 2, and delineates the importance and implementation of these competencies among first-line newsroom managers at media SMEs included in the sample.

\section{2}

\section{Problem statement}

Results from Audit 1 suggest that an adjustment in newsroom management styles and approaches could improve human resources management in newsrooms (see Steyn \& De Beer, 2002). While this implies that newsroom managers are trying to improve the human aspects of management (see Rue \& Byars, 2000), these approaches are not traditionally associated with newsroom management (see Peters, 2004; Underwood, 1995; Rankin, 1986).

By applying general management theory (see Hellriegel et al., 2004; Lussier, 2003; Daft, 2003) to newsroom management (see Peters, 2004; Graham \& Thompson, 2001), this study aims to determine the attitude of first-line newsroom managers ${ }^{2}$ and reporters in South African mainstream media ${ }^{3}$ to six important managerial competencies, namely communication, planning and administration, strategic action, teamwork, global awareness and self-management (identified by Hellriegel et al., 2004). It also aims to ascertain how these competencies are currently implemented in South African newsrooms. As indicated above, this article focuses on the media. SMEs ${ }^{4}$ were included in the sample.

\section{3}

\section{Theoretical framework}

\subsection{Managerial competencies}

Kroon (1995: 7-8) describes management as a process by which people in leadership positions (managers) apply human and other resources as efficiently as possible to deliver need-satisfying products or services and to eventually realise a business enterprises' predetermined goals. This implies the implementation of basic (i.e. planning, organising, leading and control) and additional (decision making, communication, motivating, co-ordinating, delegating and disciplining) management functions (Ivancevich, Lorenzi, Skinner \& Crosby, 1997). It also implies that managers are skilled in managerial competencies (Hellriegel, et al., 2001: 5). These requirements also apply to media newsroom management.

However, the study of the phenomenon of media management is still a fairly new field in South Africa. Results from Audit 1 underscore the necessity of improving journalists' skills and performance through improving human resources management (see Steyn \& De Beer, 2002; also Hellriegel et al., 2001: 5). Changed organisational environments further heighten this need (see Gade, 2004; Cameron, 2003; Rensburg \& Cant, 2003).

To achieve this improvement in skills and performance, managers require managerial competencies (Hellriegel et al., 2001; Oosthuizen, De Bruyn, Jacobs \& Kruger, 2002: 29-32)

in the following fields ${ }^{5}$ :

- Communication: Managers are required to promote understanding between themselves and staff members through proper communication. Unfortunately, newsrooms are often notorious for poor internal communication (see Peters, 2004: 5; Fink, 1996: 96). In the context of a multi-cultural South African newsroom, proper internal communication is even more important (see De Beer \& Steyn, 2002: 70).

- Planning and administration: Managers are also required to plan properly in order to effectively and efficiently achieve 
organisational goals and objectives (see Kroon \& Van Zyl, 1995). In the increasingly competitive media environment, proper planning and administration skills are critical (see Hollifield, 2003; Fink, 1996: 78; Rankin, 1986: 33). These skills include the ability to utilise time and financial resources wisely (see Berger, 2004; De Beer \& Steyn, 2002: 63).

- Strategic action: Managers must understand both the micro- and macro-contexts in which they work (see Lussier, 2003; KungShankleman, 2000). This enables them to manage change effectively (see Gade, 2004) and improve organisational output (see Jones, 2003).

- Teamwork: Managers (also in the media) are increasingly challenged to accomplish organisational goals and objectives through small, interdependent and jointly responsible groups of employees (Lussier, 2003; Thompson, 2001: 7). However, the traditional notion that journalists work independently makes this a difficult task for media managers (see Fink, 1996: 80).

- Global awareness: Trends related to globalisation and increased cross-border business activity require managers to be wellversed in cultural differences (see Hellriegel et al., 2004). However, the multicultural nature of the South African society additionally requires media managers to be sensitive towards these differences in the local context (see Nsidi, 2002).

- Self-management: Managers are not only responsible for the development of their own professional and private lives, but also those of their staff members (see Hellriegel et al., 2004; Montgomery, Peeters, Schaufeli \& Den Ouden, 2003). This implies the ability to admit mistakes and act in an ethically acceptable manner (see De Beer \& Steyn, 2002: 72; Gaziano \& Coulson, 1988: 871).

\subsection{South African SMEs}

\subsubsection{Definition of media SMEs}

The National Small Business Act (102/1996) defines a South African SME in the transport, storage and communication industries as having 200 or fewer full-time or equivalent paid employees, realising a total annual turnover of R26 million or less and disposing over a total gross asset value (fixed property excluded) of R6 million or less. The schedule containing this definition was replaced in 2003 by section 7 of the National Small Business Amendment Act (26/2003). The 2003 substitution, however, maintains the exact parameters for a transport, storage or communication SME specified in the 1996 Act. This is unfortunate, as the values for annual turnover and asset value must be adjusted to take the changing value of money into account.

Hoag (2005) defines media entrepreneurship as "the creation and ownership of a small enterprise or organisation whose activity adds at least one voice or innovation to the media marketplace". This includes new entrants, existing small enterprises, and for-profit and non-commercial forms of enterprise, but excludes big media. The result of successful media entrepreneurship which adds voices to the media marketplace is eventually the creation of small and medium-sized media enterprises. This was illustrated in the South African media landscape with the commercialisation of the radio stations operated by the South African Broadcasting Corporation (SABC) in the mid-1990s. As part of its unbundling process, the SABC sold off a number of radio stations to private owners. While this was positive in the sense that new voices were added to the South African media environment, it left these new radio station owners and staff with the challenge of competing with well-established voices in the market. Moreover, they were forced to find innovative ways through which they could manage the stations to the benefit of all those involved, including owners, staff members and audiences. One specific challenge they had to overcome was related to human resource management. After a station was sold, its employees lost all the benefits they enjoyed when their station was part of the SABC (e.g. medical aid schemes, pension funds). Over and above these, they also had to address challenges related to physical infrastructure and technology (see Steyn \& Steyn, 2003). Nevertheless, today 
the majority of these radio stations are now playing an important role in setting and covering the country's news agenda.

In this context and for the purposes of this article, therefore, media SMEs are defined as media enterprises not forming part of the big media organisations in South Africa (i.e. Media 24, Johnnic, Independent and Caxton), but that operated (at time of Audit 2) as independent SMEs or as independent SME business units in investment portfolios of larger conglomerates. This implies that the Small Business Act guidelines are taken into account. Media enterprises that originated from the commercialisation of SABC radio stations as well as radio stations that originated from greenfield licensing initiatives of the former Independent Broadcasting Authority (IBA) are also included (given Hoag's 2005 definition), even though these radio stations might form part of the investment portfolios of larger conglomerates.

\subsubsection{Managerial competencies at South African SMEs}

The important contribution made by the estimated 3 million small enterprises in South Africa (including informal enterprises) (South Africa Yearbook, 2004/05: 173) to the South African national economy in terms of creating employment and contributing to gross domestic product (GDP) is undisputable. More than 50 per cent of the people formally employed and 42 per cent of South African GDP can be attributed to small and medium-sized enterprises (South Africa Yearbook, 2000/01: 158).

Unfortunately, the failure rate among SMEs is high; it is estimated that between 70 per cent and 80 per cent of South African SMEs fail (Moodie, 2003: 9; Barron, 2000: 1) compared to 85 per cent in the rest of Africa (Gaomab, 2004: 2). External (socio-economic and institutional) factors as well as internal factors (personal characteristics of the entrepreneur) directly affect enterprise success (Guzman \& Santos, 2001). However, Glueck (1980: 65) and Anon (1998: 1) agree that more than 90 per cent of failures can be attributed to "a lack of abilities to perform managerial functions" (Venter, et al., 2003: 3). Wright (1995: 75) concurs, arguing that poor management is one of the main contributors to small business failure. Clover and Darroch (2005: 244) list management skills as one of the constraints to small business survival and growth, while Kyambalesa (1994: 174) regards managerial competencies as paramount for the success of small business owner-managers.

Visagie (1997) found in a study of 116 South African small, micro and medium enterprises (SMMEs) that communication and issues related to strategic action are important managerial competencies required to manage an SMME in a changing environment. From a study among 242 small businesses in the Nelson Mandela Metropole, Venter et al., (2003) conclude that the managerial competencies most evident in a successful small business are planning and administration, strategic action and self-management. They also establish that the competencies most in need of improvement include communication, planning and administration, financial planning and teamwork. In a study of 44 agribusiness SMMEs in Kwazulu-Natal, Clover and Darroch (2005) identify, amongst others, "management capacity in the enterprise" as a constraint on agribusiness SMME survival and growth. The dimensions of this constraint are related to factors constituting the strategic action competency described in section 3.1.

It is therefore evident that managerial competencies (as identified in section 3.1) are important for SME success. This is also true for media SMEs as defined above. The next section of the article outlines the purpose, objectives and design of the study investigating managerial competencies as implemented in South African media SMEs.

\section{4}

\section{Research purpose, objectives and methodology}

\subsection{Research purpose and objective}

Given the general research purpose described above (also see Steyn, De Beer \& Steyn, 2005a), the objective of this article is to report on the importance and implementation of the six managerial competencies by first-line news 
managers in South African mainstream media SMEs.

\subsection{Research methodology}

Increasing agreement exists that a combination of qualitative and quantitative research designs (despite their differences) provides more reliable and valid research results than a single methodology, as it helps overcome the biases of both methodologies (see Neuman, 2004: 82; Babbie \& Mouton, 2001: 275-276; Du Plooy, 2001: 39; Struwig \& Stead, 2001: 19). As a result, this study combines qualitative and quantitative designs triangularly in order to obtain the best possible insight into the research problem (also see section 4.2.2). More specifically, data triangulation, investigator/researcher triangulation, methodological triangulation and interdisciplinary triangulation are used (Janesick, 1994: 214-215; also see Steyn, De Beer \& Steyn, 2005a, 2005b).

\subsubsection{Sample frame and sampling considerations}

In determining the sample frame of South African mainstream media ( $\mathrm{n}=106$ of which 20 represent SMEs) from which the sample was drawn, two fixed variables were considered, namely media type and media ownership type. Important considerations relating to these variables include the following:

- All national media types producing and distributing news had to be included in the sample frame. Therefore, using the knowledge and previous research experience of the researchers and members of SANEF and considering the requirements of a systematic random sample, a sample of 47 media was selected to include all media types. This included 12 media SMEs, representing two weekly newspapers, eight radio stations and two news agencies.

- Media ownership had to be considered, especially given the widespread changes in South African media ownership since 1994. These changes include deregulation, foreign media ownership, the presence of community and commercial media and black economic empowerment. Subsequently the sample of 12 media SMEs included (given the parameters discussed in section 3.2.1) seven unlisted and five Johannesburg Securities Exchange (JSE) listed companies. The JSE listings were obtained through a media SME owned by a listed holding company (see section 3.2.1 above).

- The sample needed to be nationally representative. No comparisons of data were, however, made on the basis of geographical location. The geographical distribution of media SMEs in the research sample included two enterprises from Cape Town, six from Johannesburg/Pretoria, one from Durban, one from Port Elizabeth, one from Bloemfontein and one from Nelspruit.

- The aim of the sampling procedure was to compile a representative sample of the country's mainstream media from which valid and reliable research results could be obtained and generalised across the sample frame. The sampling procedure thus entailed the following:

- compiling the research population of media ( $\mathrm{N}=106$ including 20 SMEs);

- calculating a proportional sample according to media type and media ownership type;

- drawing a systematic random sample of media sites ( $\mathrm{n}=47$, including 12 SMEs);

- dividing the sample into geographical areas;

- drawing a volunteer and availability sample of first-line news managers at the identified media sites during realtime fieldwork visits and

- drawing a volunteer and availability sample of reporters (reporting directly to the above managers) available at the media sites during real-time fieldwork visits.

\subsubsection{Research instruments}

The research used tree research instruments, namely:

- Quantitative self-administered questionnaires for first-line news managers: These questionnaires were administered to 
gather information about the first-line news managers' professional profiles, their attitudes towards specific professional issues and the importance and implementation of the six managerial competencies. A total of 13 first-line managers from media SMEs completed questionnaires at the sites visited $(\mathrm{n}=13)$;

- Quantitative self-administered questionnaires for reporters: In a similar fashion, questionnaires were used to compile data on reporters' professional profiles, their attitudes towards specific professional issues, the importance they attach to the six managerial competencies and their perception of how well their first-line news managers implement these competencies. A total of 59 reporters from media SMEs completed questionnaires at the sites visited $(\mathrm{n}=59)$.

Respondents (first-line news managers and reporters) included in the volunteer and availability sample were issued with questionnaires at the start of the fieldwork visit. They returned the questionnaires at the end of the fieldwork session. Respondents were assured of anonymity in an attempt to ensure the most reliable responses possible. Professional profiles were determined using closed questions, while attitudes and perceptions (about the importance and implementation of the six managerial competencies by first-line news managers) were measured using items arranged on a 5 point Likert scale (1 representing the most negative attitude/perception, and 5 representing the most positive attitude/ perception). Finally, open-ended questions encouraged respondents to identify factors hampering or promoting first-line news managers' professional performances.

- Interviews: To obtain qualitative research data, semi-structured interviews were arranged with people in charge of the media sites (e.g. editors, news editors, regional editors or current affairs editors). In cases where these editorial managers were unavailable for interviews, another staff member was delegated as interviewee. Observational research played a particularly important role in these interviews; in other words (see Denzin \& Lincoln, 1994: 378), the researchers noted and recorded, amongst others signs, verbal and non-verbal communication related to newsroom management and the implementation of the six managerial competencies. Conducting fieldwork in real-time and natural newsroom situations facilitated this process. A total of 13 interviews were conducted at media SMEs $(n=13)$.

\subsubsection{Data analysis}

Quantitative data was analysed through SAS software (SAS Institute, 1999). Both quantitative research instruments were tested for validity using Confirmatory Factor Analysis (CFA) and for reliability using Cronbach's Alpha (CA) coefficients. The CFA indicated that both questionnaires were valid by retaining at most two factors per construct (according to the Mineigen criterion). This explains at least 70.5 per cent of the variance. The CA coefficients indicated that the questionnaire for first-line managers was reliable, ranging between 0.84 and 0.98 for the respective constructs, and that the questionnaire for reporters was also reliable, ranging between 0.94 and 0.98 for the respective constructs.

Effect sizes (Ellis \& Steyn, 2003: 52; Cohen, 1988: 20-27) ${ }^{6}$ were calculated to test for significant practical differences between reporters' opinions and those of the managers, about firstly, the importance of the identified managerial competencies, and secondly, the managers' implementation of these competencies. These calculations were done across media types.

The research data in the form of interviews and notes made as part of the observational research process were analysed through qualitative content analysis (see Hocking, Stacks $\&$ McDermott, 2003: 172).

\section{5 \\ Research results}

The results obtained from the media SMEs included in the national sample for Audit 2 will now be discussed. 


\subsection{Communication as a managerial competency}

The empirical results for communication as a managerial competency are reported in Table 1.

Table 1

Empirical results for communication as a managerial competency

\begin{tabular}{|l|c|c|}
\hline & Reporters & Managers \\
\hline $\begin{array}{l}\text { Respective effect sizes for difference between importance and } \\
\text { implementation }\end{array}$ & $\mathrm{d}=0.47$ & $\mathrm{~d}=1.50$ \\
\hline $\begin{array}{l}\text { Effects size for difference between implementation (reporters) and } \\
\text { implementation (managers) }\end{array}$ & $\mathrm{c} d=0.08$ \\
\hline Respective means for implementation & Radio stations & News agencies \\
\hline Effect sizes and means for difference in implementation across media types (reporters' perspective) \\
\hline \multicolumn{2}{|c|}{$\mathrm{d}=0.73$} & $\mathrm{~d}=0.41$ \\
\hline Weekly newspapers $(\mathrm{x}=2.84)$ & $\mathrm{d}=0.46$ \\
\hline Radio stations $(\mathrm{x}=3.82)$ & $\mathrm{News}$ agencies & \\
\hline News agencies $(\mathrm{x}=3.39)$ & $\mathrm{d}=0.49$ & \\
\hline Effect size and means for difference in implementation across media types (managers' perspective) \\
\hline
\end{tabular}

Comparing the effect sizes for the differences between importance and implementation as judged by reporters $(\mathrm{d}=0.47)$ and managers $(d=1.50)$ clearly shows that managers feel more acutely aware than reporters do of their inability to communicate as well as they think they should. The effect size of 0.08 indicates no significant difference between the implementation of communication competencies of reporters and managers. Generally, reporters and managers thus agree on managers' implementation of communication, with managers rating themselves marginally higher $(x=3.42)$ than reporters rate their managers $(x=3.33)$.

Looking at the implementation of communication among reporters across the three different media types (i.e. weekly newspapers, independent radio stations and news agencies), it is interesting to note a significant difference $(d=0.73)$ between weekly newspapers and radio stations. Managers at the radio stations $(x=3.82)$ achieve better results than those at the weekly newspapers $(x=2.84)$. A moderate effect $(\mathrm{d}=0.41)$ is also seen between weekly newspapers and news agencies, with reporters rating managers at news agencies $(x=3.39)$ better than those at weekly newspapers. The same applies for managers at radio stations compared to those at news agencies $(d=0.46)$.

From the perspective of managers in the different media types, ${ }^{7}$ there is a moderate difference $(d=0.49)$ in their judgement of the implementation of communication between weekly newspapers and news agencies. Managers at the newspapers $(x=3.61)$ regard themselves as better at implementing this competency than those at news agencies $(x=3.28)$. A content editor at a radio station admitted 
that communication can be problematic even though these newsrooms are run by small teams. Generally, however, the respondents stress the importance of being available to reporters in an attempt to guide them through the news gathering and writing processes as well as to give feedback. Managers also say that open communication is important in helping to clarify misunderstandings with and between reporters.

\subsection{Planning and administration as a managerial competency}

The empirical results for planning and administration as a managerial competency are reported in Table 2.

Table 2

Empirical results for planning and administration as a managerial competency

\begin{tabular}{|c|c|c|}
\hline & Reporters & Managers \\
\hline $\begin{array}{l}\text { Respective effect sizes for difference between importance and } \\
\text { implementation }\end{array}$ & $\mathrm{d}=0.41$ & $\mathrm{~d}=0.52$ \\
\hline $\begin{array}{l}\text { Effects size for difference between implementation (reporters) and } \\
\text { implementation (managers) }\end{array}$ & \multicolumn{2}{|c|}{$\mathrm{d}=0.05$} \\
\hline Respective means for implementation & $x=3.50$ & $x=3.55$ \\
\hline \multicolumn{3}{|c|}{ Effect sizes and means for difference in implementation across media types (reporters' perspective) } \\
\hline & Radio stations & News agencies \\
\hline Weekly newspapers $(x=3.08)$ & $d=0.68$ & $\mathrm{~d}=0.42$ \\
\hline Radio stations $(x=3.90)$ & & $d=0.34$ \\
\hline \multicolumn{3}{|l|}{ News agencies $(x=3.59)$} \\
\hline \multicolumn{3}{|c|}{ Effect size and means for difference in implementation across media types (managers' perspective) } \\
\hline & News agencies & \\
\hline Weekly newspapers $(x=3.42)$ & $\mathrm{d}=0.42$ & \\
\hline News agencies $(x=3.80)$ & & \\
\hline
\end{tabular}

As far as the planning and administration competency is concerned, there is a moderate but significant difference in the opinions of both reporters $(\mathrm{d}=0.41)$ and managers $(\mathrm{d}=0.52)$ between importance and current implementation. Comparing the opinions of reporters and managers about the implementation of the planning and administration competency yields an effect size of 0.05 , which indicates no significant difference. Generally, reporters and managers thus agree on managers' implementation of this competency. However, managers rate themselves marginally higher $(x=3.55)$ than reporters rate their managers $(x=3.50)$.

Reporters' views of the implementation of planning and administration differs moderately between both weekly newspapers and radio stations $(d=0.68)$ and weekly newspapers and news agencies $(\mathrm{d}=0.42)$. No significant difference exists however between reporters from radio stations and news agencies $(\mathrm{d}=0.34)$. Reporters at radio stations $(x=3.90)$ again award their managers higher scores than do their counterparts at news agencies $(x=3.59)$ and at weekly newspapers $(x=3.08)$.

From the managers' perspective, there is a moderate difference $(\mathrm{d}=0.42)$ of opinion about the implementation of this competency between weekly newspapers and news agencies. Managers at news agencies $(x=3.80)$ perceive themselves as better implementers than those at weekly newspapers $(x=3.42)$. Managers at radio 
stations complain about a lack of time to plan in advance what they expect of reporters and what they expect of themselves. The managers mainly ascribe the situation to the amount of time they spend "on air" themselves. Another contributing factor is the nature of the product which complicates medium to long-term planning, as breaking news cannot always be planned for.

\subsection{Strategic action as a managerial competency}

The empirical results for strategic action as a managerial competency are reported in Table 3.

Table 3

Empirical results for strategic action as a managerial competency

\begin{tabular}{|l|c|c|}
\hline & Reporters & Managers \\
\hline $\begin{array}{l}\text { Respective effect sizes for difference between importance and } \\
\text { implementation }\end{array}$ & $\mathrm{d}=0.32$ & $\mathrm{~d}=1.03$ \\
\hline $\begin{array}{l}\text { Effects size for difference between implementation (reporters) and } \\
\text { implementation (managers) }\end{array}$ & $\mathrm{c} d=0.13$ \\
\hline Respective means for implementation & $\mathrm{x}=3.64$ & $\mathrm{x}=3.49$ \\
\hline Effect sizes and means for difference in implementation across media types (reporters' perspective)
\end{tabular}

As can be seen in Table 3, managers regard this competency as an area in which they perform significantly below $(\mathrm{d}=1.03)$ what would be expected for the importance they attach to it. Reporters, on the other hand, do not regard their managers as failing to implement strategic action tasks compared to the importance they attach to it $(\mathrm{d}=0.32)$.

For the implementation of strategic action, a comparison of the opinions of reporters and managers indicates no significant difference $(d=0.13)$. Generally, reporters and managers thus agree on managers' implementation of strategic action, with reporters rating their managers marginally higher $(x=3.64)$ than managers rate themselves $(x=3.49)$.
The opinions of reporters at the different media types show significant differences for their managers' implementation of strategic action. This is the case between weekly newspapers and radio stations $(\mathrm{d}=0.82)$, as well as between weekly newspapers and news agencies $(d=0.77)$. An insignificant difference was also found between radio stations and news agencies $(d=0.07)$. Managers at radio stations $(x=4.08)$ again achieve better results than their counterparts at news agencies $(x=4.02)$ and weekly newspapers $(x=3.11)$.

A moderate but significant difference was also calculated for the implementation of strategic action among managers from weekly newspapers as opposed to among those at news 
agencies $(d=0.42)$. Managers at the newspapers $(x=3.79)$ regard themselves better implementers than do managers at news agencies $(x=3.20)$. Managers at radio stations generally indicate that they (and their newsroom staff) are aware of the expectations of their target audience concerning the news product. One news editor, however, admitted that "he has a general sense of what they are about", and that since joining the newsroom he has not actively used available information on audience characteristics. Two other news editors felt that the newsroom "is an island in the bigger organisation" and should be purposefully integrated into the wider organisation to a greater extent.

\subsection{Teamwork as a managerial competency}

The empirical results for teamwork as a managerial competency are reported in Table 4.

\section{Table 4}

Empirical results for teamwork as a managerial competency

\begin{tabular}{|l|c|c|}
\hline & Reporters & Managers \\
\hline $\begin{array}{l}\text { Respective effect sizes for difference between importance and } \\
\text { implementation }\end{array}$ & $\mathrm{d}=0.47$ & $\mathrm{~d}=0.26$ \\
\hline $\begin{array}{l}\text { Effects size for difference between implementation (reporters) and } \\
\text { implementation (managers) }\end{array}$ & \multicolumn{1}{|c|}{$\mathrm{d}=0.42$} \\
\hline Respective means for implementation & \multicolumn{1}{|c|}{$\mathrm{x}=3.35$} \\
\hline Effect sizes and means for difference in implementation across media types (reporters' perspective)
\end{tabular}

Table 4 indicates that reporters regard teamwork as an area in which their managers perform moderately worse $(d=0.47)$ than would be expected for importance they attach to it. Managers, on the other hand, do not regard themselves as failing to implement teamwork tasks compared with the importance they afford it $(\mathrm{d}=0.26)$.

Comparing the opinions of implementation of teamwork between reporters and managers shows a moderate difference $(\mathrm{d}=0.42)$ between them. Reporters $(x=3.35)$ believe that their managers $(x=3.87)$ implement teamwork slightly more poorly than managers believe to be the case.

Reporters at the different media types believe that a moderate difference exists between managers at weekly newspapers and radio stations $(\mathrm{d}=0.67)$. Insignificant differences were found between radio stations and news agencies $(\mathrm{d}=0.38)$, as well as between weekly newspapers and news agencies $(d=0.31)$. Reporters at radio stations $(x=3.82)$ once again regard their managers as better at teamwork than do their counterparts at news agencies $(x=3.34)$ and at weekly newspapers $(x=2.91)$. 
Managers at weekly newspapers and those at news agencies highlighted an insignificant difference $(\mathrm{d}=0.04)$ for their implementation of teamwork. Managers at news agencies $(x=3.94)$ regard themselves as marginally better than their peers at weekly newspapers $(x=3.91)$. Managers at radio stations seem split over the issue of teamwork. Some dismiss it outright, while others regard it as "highly important" and as fulfilling "a crucial role". Managers see sharing recognition for the team effort among all the contributors as their biggest management challenge. Reporters, however, are more concerned with other aspects of teamwork (see section 6.4).

\subsection{Global awareness as a managerial competency}

The empirical results for global awareness as a managerial competency are reported in Table 5.

Table 5

Empirical results for global awareness as a managerial competency

\begin{tabular}{|l|c|c|}
\hline & Reporters & Managers \\
\hline $\begin{array}{l}\text { Respective effect sizes for difference between importance and } \\
\text { implementation }\end{array}$ & $\mathrm{d}=0.47$ & $\mathrm{~d}=1.07$ \\
\hline $\begin{array}{l}\text { Effects size for difference between implementation (reporters) and } \\
\text { implementation (managers) }\end{array}$ & $\mathrm{d}=0.04$ \\
\hline Respective means for implementation & Radio stations & News agencies \\
\hline Effect sizes and means for difference in implementation across media types (reporters' perspective) \\
\hline \multicolumn{2}{|c|}{$\mathrm{d}=0.73$} & $\mathrm{~d}=0.11$ \\
\hline Weekly newspapers $(\mathrm{x}=3.17)$ & & $\mathrm{d}=0.77$ \\
\hline Radio stations $(\mathrm{x}=4.16)$ & $\mathrm{News}$ agencies & \\
\hline News agencies $(\mathrm{x}=3.32)$ & $\mathrm{d}=0.07$ & \\
\hline Effect size and means for difference in implementation across media types (managers' perspective) \\
\hline
\end{tabular}

Comparing the difference in opinions about the importance and implementation of global awareness as a managerial competency of reporters $(d=0.47)$ and managers $(d=1.07)$ clearly shows that managers regard this as an area in which they perform significantly worse than they think they should. Reporters, on the other hand, regard their managers as only failing moderately in implementing global awareness tasks compared to the importance they afford it.

Comparing opinions of the implementation of global awareness among reporters and managers yields an effect size of 0.04 , indicating an insignificant difference. Both groups agree on managers' implementation of global awareness, with managers rating themselves marginally higher $(x=3.66)$ than reporters do $(x=3.61)$.

Reporters across the three media types indicate significant differences for the implementation of global awareness by their respective managers. This is the case between both weekly newspapers and radio stations $(\mathrm{d}=0.73)$ and radio stations and news agencies $(d=0.77)$. An insignificant difference was found between weekly newspapers and news agencies $(\mathrm{d}=0.11)$. Reporters at radio stations $(x=4.16)$ once again regard their managers as better at 
implementing global awareness than do their counterparts at news agencies $(x=3.32)$ and weekly newspapers $(x=3.17)$.

Managers at weekly newspapers (when compared with those at news agencies) indicate an insignificant difference $(\mathrm{d}=0.07)$ on their implementation of global awareness tasks. Managers at news agencies $(x=3.69)$ regard themselves as marginally better than those at weekly newspapers $(x=3.63)$. Managers at radio stations believe that ethnic and multi-cultural issues do not create newsroom conflict. As one news editor put it, "Ten years ago you did not discuss some issues among people, [but now these] differences become humorous". Radio newsrooms also display interesting demographics reflecting their target audiences. Some are exclusively English and Afrikaans (although not exclusively white), others have a mixed composition and others are "all black".

\subsection{Self-management as a managerial competency}

The empirical results for self-management as a managerial competency are reported in Table 6.

Table 6

Empirical results for self-management as a managerial competency

\begin{tabular}{|l|c|c|}
\hline & Reporters & Managers \\
\hline $\begin{array}{l}\text { Respective effect sizes for difference between importance and } \\
\text { implementation }\end{array}$ & $\mathrm{d}=0.51$ & $\mathrm{D}=1.07$ \\
\hline $\begin{array}{l}\text { Effects size for difference between implementation (reporters) and } \\
\text { implementation (managers) }\end{array}$ & \multicolumn{1}{|c|}{$\mathrm{d}=0.37$} \\
\hline Respective means for implementation & $\mathrm{x}=4.61$ & \multicolumn{2}{|c|}{$\mathrm{d}=0.33$} \\
\hline Effect sizes and means for difference in implementation across media types (reporters' perspective)
\end{tabular}

Comparing opinions about the importance and implementation of self-management as a managerial competency among reporters $(d=0.51)$ and managers $(d=1.07)$, it is evident that managers regard this as an area in which they perform significantly more poorly than they think they should. Reporters, on the other hand, only regard their managers as failing moderately in implementing self-management tasks compared to the importance they afford this competency.
In terms of implementation, an effect size of 0.37 indicates an insignificant difference between the two groups. Generally, reporters and managers agree about managers' implementation of self-management, with managers rating themselves only slightly higher $(x=4.05)$ than reporters do $(x=3.61)$.

Reporters across the three media types believe moderately differently about the implementation of self-management by their managers. This is the case between weekly 
newspapers and radio stations $(\mathrm{d}=0.64)$ as well as between radio stations and news agencies $(d=0.45)$. An insignificant difference is found between weekly newspapers and news agencies $(\mathrm{d}=0.33)$. Reporters at radio stations $(x=4.06)$ once again regard their managers as better at this competency than do their counterparts at news agencies $(x=3.64)$ and at weekly newspapers $(x=3.18)$.

An insignificant difference $(d=0.04)$ of opinion can be found about the implementation of self-management between managers at weekly newspapers and those at news agencies. The newspaper managers $(x=4.08)$ regard themselves as marginally better than do the managers at news agencies $(x=4.06)$. For managers at radio stations, the biggest challenge seems to lie in helping their reporters to develop a well balanced work-life attitude. All the interviewees stated that their staff work hard and do many hours of overtime for which they do not necessarily get paid. Managers mostly see themselves as having a good work-life balance, while acknowledging that they can never switch off completely from what is going on in the newsroom. They can be called at any time to help solve problems with stories for the next morning. Interestingly, most managers admit that their newsrooms do not function according to a formalised code of ethics, but only according to "broad guidelines" formulated from their own experiences in the industry.

\section{6}

\section{Conclusions and managerial implications}

A number of the findings reported above are very interesting, and yield the following conclusions and managerial implications.

\subsection{Communication as a managerial competency}

The results shows that first-line newsroom managers at mainstream media SMEs in South Africa do not communicate with their subordinate reporters as well as they themselves would like to. Reporters, however, do not feel as concerned about this issue as their managers. As far as the implementation of communication is concerned, both reporters and managers agree on managers' competence.

Reporters perceive a practically significant difference between the way managers at radio stations communicate with them as compared to those at weekly newspapers. Reporters also believe that these newspaper managers most urgently need to brush up on their communication skills, followed by managers at news agencies and then managers at radio stations. Interestingly, however, managers at weekly newspapers distinguish themselves as communicating better with a moderate effect size from their colleagues at news agencies.

Taking into account the items for which reporters indicate a moderate effect size (no practically significant effect sizes were indicated), managers might be able to improve reporters' perception of their communication competency as managers by

- using technological resources (e.g. e-mail) more to communicate with reporters. This is important, as managers seem unaware that their failure to do so is a problem for reporters. Managers at radio stations are, however, especially aware that e-mail communication is not suitable in every circumstance. People can be offensive on e-mail because they do not have to confront each other personally. One duty editor informed the research team that her station has adopted a policy stating how people should address each other, especially when writing e-mails;

- maintaining sound interpersonal relationships with reporters;

- taking reporters' feelings and emotions into account during communication;

- negotiating resources that reporters need to perform their jobs and

- improving their language skills to facilitate communication and address multi-lingual differences in the work environment. This is especially important since only 24.56 per cent of reporters name English as their mother tongue, while 75 per cent of them say they communicate in English most of the time at work. Only 18.52 per cent of 
reporters say they are able to communicate 100 per cent of the time at work in their mother tongue, while nearly half of them (48.15 per cent) indicate that they spend only 50 per cent or less of their time at work communicating in their mother tongue.

\subsection{Planning and administration as a managerial competency}

Both reporters and first-line managers regard planning and administration as a managerial competency of moderate importance.

Reporters highlight a moderate difference between the way in which managers at weekly newspapers implement the planning and administration competency compared to those at radio stations and news agencies respectively. Reporters once again believe that managers at weekly newspapers should improve on their planning and administration competency most urgently, followed by managers at news agencies and then managers at radio stations. Managers at weekly newspapers accept this, as they evaluate themselves lower at implementing planning and administration than do managers at news agencies.

Taking into account the items for which reporters indicate a moderate effect size (no practically significant effect sizes were indicated), managers might be able to improve reporters' perception of their planning and administration competency as managers by

- defending more tenaciously to top management the consequences of financial and other risks taken in order to develop the news product;

- pro-actively developing plans to improve levels of professional output;

- obtaining the resources needed to deliver the news product (also see section 6.1) and

- organising these resources more effectively.

\subsection{Strategic action as a managerial competency}

First-line managers are aware to a significant extent that they do not implement strategic action as a managerial competency as well as they would like to. Reporters, on the other hand, do not consider this to be a problem.

Reporters again highlight a practically significant difference in the implementation of this competency by managers at weekly newspapers compared to their peers at both radio stations and news agencies. Reporters overall believe that managers at weekly newspapers most urgently need to improve their strategic action competency, followed by managers at news agencies and then those at radio stations. Interestingly, however, the managers at weekly newspapers again distinguish themselves with a moderate effect size from their colleagues at news agencies in terms of implementing the strategic action competency better.

Taking into account the items for which reporters indicate a moderate effect size (no practically significant effect sizes were indicated), managers might be able to improve reporters' perception of their strategic action competency as managers by

- monitoring changes in the department/ section more closely to identify the strengths, weaknesses, opportunities and threats that influence the performance of the section/ department;

- making a deliberate effort to understand the concerns of reporters better and

- making a deliberate effort to understand the nature of the news product in the context of the target audience better.

\subsection{Teamwork as a managerial competency}

As far as teamwork as a managerial competency is concerned, reporters are clearly more aggrieved by their first-line managers' implementation of this competency than managers themselves are. This is substantiated by the moderate effect size indicated between reporters' and managers' evaluation of managers' implementation of the competency.

From the reporters' point of view, there is only a moderate difference between the way in which managers at weekly newspapers implement teamwork and the way in which managers at radio stations do. Practically insignificant 
differences exist between news agencies and weekly newspapers, as well as between news agencies and radio stations. This once again confirms that teamwork as a managerial competency among first-line managers in South African media SMEs is a weakness throughout the industry. Reporters again believe that managers at weekly newspapers most urgently need to improve their teamwork competency, followed by managers at news agencies and then those at radio stations. Managers at weekly newspapers agree, as they indicate that their implementation of teamwork is inferior to that of their colleagues at news agencies.

Taking into account the items for which reporters indicate a moderate effect size (no practically significant effect sizes were indicated), managers might be able to improve reporters' perception of their teamwork competency as managers by

- structuring the department/section to implement teamwork principles;

- assisting reporters in acquiring the knowledge needed to function within a teamwork structure;

- defining individual objectives within the teamwork environment;

- coaching, mentoring and counselling reporters throughout a team project;

- understanding reporters' individual strengths and weaknesses within a teamwork structure;

- sharing recognition and credit with team members;

- $\quad$ sharing the responsibilities associated with implementing teamwork;

- creating an environment where teamwork is rewarded and

- praising reporters in the department/ section.

Attending to these steps could also help to address managers' concern with their inability to optimally manage team conflict. If reporters are more satisfied with their manager's implementation of teamwork, less team conflict may result, alleviating the load of conflict managers have to handle.

\subsection{Global awareness as a managerial competency}

As far as global awareness is concerned, managers are clearly more disappointed by their own implementation of this managerial competency than reporters are, compared to the importance both groups attach to it. When only taking implementation into account, both groups agree on managers' implementation, as shown by an insignificant effect size.

Reporters indicate practically significant differences between the implementation of global awareness by managers at radio stations compared to managers at weekly newspapers and news agencies. A practically insignificant difference is indicated between news agencies and weekly newspapers. Reporters therefore believe that managers at weekly newspapers and news agencies should most urgently improve their global awareness competency. Managers at radio stations are rated significantly higher for the implementation of this competency than their counterparts in the other two media types. Managers at weekly newspapers agree with this judgement, as they see their implementation of the global awareness competency as inferior to that of their colleagues at news agencies.

Taking into account the items for which reporters indicate a moderate effect size (no practically significant effect sizes were indicated), managers might be able to improve reporters' perception of their global awareness competency as managers by

- acquiring multi-lingual skills. In a country like South Africa, which has 11 official languages, managers cannot realistically be expected to converse perfectly in all these languages. However, reporters will appreciate attempts to communicate with them in their mother tongue (given the situation discussed in section 6.1); and

- cultivating a sensitivity for ethnic and cultural differences and a willingness to understand, adapt to and adjust behaviour according to these differences. 


\subsection{Self-management as a managerial competency}

Managers seem more disappointed with their own implementation of self-management than reporters, given the importance both groups attach to it. When taking only implementation into account, both groups agree on managers' implementation, as is shown by the insignificant effect size between these variables.

Reporters highlight moderate differences between the implementation of self-management by managers at radio stations compared to that of managers at weekly newspapers and news agencies. Only a practically insignificant difference exists between managers at news agencies and weekly newspapers. Reporters again believe that managers at weekly newspapers should most urgently improve their selfmanagement competency, followed by managers at news agencies and then those at radio stations. Interestingly in this case, managers at weekly newspapers regard themselves as implementing the competency better than do their colleagues at news agencies.

Taking into account the items for which reporters indicate a moderate effect size (no practically significant effect sizes were indicated), managers might be able to improve reporters' perception of their self-management competency as managers by

- conducting themselves according to clearly defined personal values;

- accommodating differing personal values in their reporters;

- upholding the ethical code of the news enterprise;

- $\quad$ admitting to personal mistakes;

- taking responsibility;

- maximising individual strengths;

- $\quad$ addressing individual weaknesses;

- learning from past mistakes and experiences;

- working diligently;

- persevering under conditions of failure and stress;

- finding ways to cope with secondary trauma in the newsroom and
- taking reporters' mental states into account.

\section{7}

Summary

This article investigates the managerial competencies of first-line newsroom managers in South African mainstream media SMEs as evaluated by the managers themselves and by their subordinates, the reporters. Managers regard themselves as implementing the communication, strategic action, global awareness and self-management competencies more poorly compared to the importance they attach to these competencies, than do reporters compared to the importance they attach to them. As for the planning and administration competency, reporters and managers agree that managers in general fail to a moderate degree to implement this competency. However, for the teamwork competency, reporters are more dissatisfied with managers' performance than the managers are themselves.

When comparing the implementation of these managerial competencies across media types, reporters evaluate managers at weekly newspapers as worst at implementing these competencies, followed by managers at news agencies. Managers at radio stations are held to implement all six managerial competencies best.

Evaluating the implementation of these competencies across different media types shows that managers at news agencies regard themselves more highly than do their colleagues at weekly newspapers in the case of the planning and administration, teamwork and global awareness competencies. Surprisingly, managers at weekly newspapers regard themselves as more successful in implementing the communication, strategic action and self-management competencies than do their counterparts at news agencies, despite reporters' indicating the opposite. Managers at radio stations indicate a number of issues pertaining to all six competencies that they would also like to implement better. 


\section{Endnotes}

1 Sanef provided the first author permission to use the qualitative and quantitative research data obtained from Audit 1 and Audit 2 for purposes of further research.

2 For a definition of this term see Steyn, De Beer \& Steyn (2005b: 214).

3 For a definition of this term see Steyn, De Beer \& Steyn (2005b: 214).

4 See section 3.2 for a discussion on the definition of media SMEs as applied in this article.

5 For a detailed discussion of the theoretical framework used, see Steyn, De Beer \& Steyn (2005b: 214-216).

6 The effect sizes (d-values) were calculated by using the following formula (Cohen, 1988: 20-27; also see Steyn, De Beer \& Steyn, 2005a: 44):

$\mathrm{d}=\frac{\left|\bar{x}_{1}-\bar{x}_{2}\right|}{S_{\max }}$

where:

- $\mathrm{d}=$ effect size;

- $\bar{x}_{1}-\bar{x}_{2}$ is the difference between means of two compared groups (e.g. first-line managers and reporters); and

- $s_{\text {max }}$ is the maximum standard deviation of the two compared groups.

Effect sizes were interpreted as follows (Ellis \& Steyn, 2003: 52; Cohen, 1988: 20-27):

- $\mathrm{d} \approx 0.2$ indicating a small effect with no practical significance;

- $\mathrm{d} \approx 0.5$ indicating a moderate effect; and

- $\mathrm{d} \approx 0.8$ or larger indicating a practically significant effect.

7 Results from radio station managers on this issue are not reported quantitatively, as only one manager from a small to mediumsized independent radio station completed a questionnaire. This is due to the flat organisational structures primarily found at these radio stations. Interviews were, however, conducted with eight managers at these stations. These are interpreted qualitatively. Due to the sensitive nature of the issues discussed it was agreed that interviewees would remain anonymous. Interviewees are therefore not identified in the qualitative assessment of their input.

\section{References}

1 ACTS see South Africa.

2 ANON (1998) "Limited skills in management", http://www.billrobb.co.za/smallbusiness failures. html, (Accessed 7 September 2005.)

3 BABBIE, E. \& MOUTON, J. (2001) The Practice of Social Research, Oxford University Press: Oxford.

4 BARRON, C. (2000) "Brilliant ideas but spectacular flops”, Sunday Times Business Times, 9 April: 1.

5 BERGER, G. (2004) "Miserable state of affairs", Mail \& Guardian Online, 25 March.

6 CAMERON, G. (2003) "The newspaper credibility crisis: Lessons for the classroom", Panel discussion at the Association for Education in Journalism and Mass Communication's Newspaper and Communication Technology and Policy Division 86th Annual Convention, Kansas City, 30 July-2 August.

7 CLOVER, T.A. \& DARROCH, M.A.G. (2005) "Owners' perceptions of factors that constrain the survival and growth of small, medium and micro agribusinesses in Kwazulu-Natal, South Africa”, Agrekon, 44(2): 238-263.

8 COHEN, J. (1988) Statistical Power Analysis for the Behavioural Sciences, Erlbaum: Hillsdale, NJ.

9 DAFT, R.L. (2003) Management, Thomson: SouthWestern Australia.

10 DE BEER, A.S. \& STEYN, E. (eds.) (2002) "Focus on journalism skills", Special edition of Ecquid Novi, 23(1).

11 DENZIN, N.K. \& LINCOLN, Y.S. (eds.) (1994) Handbook of Qualitative Research, Sage: Thousand Oaks.

12 DU PLOOY, G.M. (2001) Communication Research: Techniques, Methods and Applications, Juta: Landsdowne.

13 ELLIS, S.M. \& STEYN, H.S. (2003) "Practical significance (effect sizes) versus or in combination with statistical significance (p-values)", Management Dynamics: Contemporary Research, 12(4): 51-53.

14 FINK, C.C. (1996) Strategic Newspaper Management, Allyn \& Bacon: Boston.

15 GADE, P.J. (2004) "Newspapers and organizational development: management and journalist perceptions of newsroom cultural change”, Journalism Communication Monographs, $6(1)$.

16 GAOMAB. M. (2004) "Challenges facing SMEs", http://www.sarpn.org.za/documents/d0001004/ index.php, (Accessed 7 September 2005.) 
17 GAZIANO, C. \& COULSON, D.C. (1988) "Effect of newsroom management styles on journalists: A case study", Journalism Quarterly, 65: 869-880.

18 GLUECK, W.F. (1980) Management, Dryden: Illinois.

19 GRAHAM, G. \& THOMPSON, T. (2001) Inside Newsroom Teams: An Editor's Guide to the Promise and Problems, Media Management Center: Evanston, IL.

20 GUZMAN, J. \& SANTOS, F. (2001) "The booster function and entrepreneurial quality: An application to the province of Seville", Entrepreneurship and Regional Development, 13: 211-228.

21 HELLRIEGEL, D.; JACKSON, S.E.; SLOCUM, J.; STAUDE, G.; AMOS, T.; KLOPPER, H.B.; LOUW, L. \& OOSTHUIZEN, T. (2001) Management: South African Edition, Oxford University Press: Oxford.

22 HELLRIEGEL, D.; JACKSON, S.E.; SLOCUM, J.; STAUDE, G.; AMOS, T.; KLOPPER, H.B.; LOUW, L. \& OOSTHUIZEN, T. (2004) Management: South African Edition, Oxford University Press: Oxford.

23 HOAG, A. (2005) "Media entrepreneurship and management research", Paper read at the Association for Education in Journalism and Mass Communication's Media Management and Economics Division 88th Annual Convention, San Antonio, 10-13 August.

24 HOCKING, J.E.; STACKS, D.W. \& McDERMOTT, S.T. (2003) Communication Research, Allyn \& Bacon: Boston.

25 HOLLIFIELD, C.A. (2003) "Editorial: The impact of financial markets on media management practices", The International Journal on Media Management, 5(4): 136.

26 IVANCEVICH, J.M.; LORENZI, P.; SKINNER, S.J. \& CROSBY, P.B. (1997) Management: Quality and Competitiveness, Richard D. Irwin: Chicago.

27 JANESICK, V.J. (1994) "The dance of qualitative research design: Metaphor, methodology and meaning" in Denzin, N.K. \& Lincoln, Y.S. (eds.) Handbook of Qualitative Research, Sage: Thousand Oaks.

28 JONES, J. (2003) "Using webcasts to inspire staff at The New York Times company", SCM, 7(3): 1417.

29 KROON, J. (1995) "Bestuur en bestuurders [Management and managers]" in Kroon, J. (ed.), Algemene Bestuur [General management], Kagiso Tersiêr: Pretoria.

30 KROON, J. \& VAN ZYL, J.J. (1995) "Beplanning en planne [Planning and plans]" in Kroon, J. (ed.)
Algemene Bestuur [General Management], Kagiso Tersiêr: Pretoria.

31 KUNG-SHANKLEMAN, L. (2000) Inside the $B B C$ and $C N N$ : Managing Media Organizations, Routledge: London.

32 KYAMBALESA, H. (1994) Success in Managing a Small Business, Avebury.

33 LUSSIER, R.N. (2003) Management Fundamentals: Concepts, Applications, Skill Development, Thomson South-Western: Australia.

34 MONTGOMERY, A.J.; PEETERS, M.C.W.; SCHAUFELI, W.B. \& DEN OUDEN, M. (2003) "Work-home interference among newspaper managers: Its relationship with burnout and engagement", Anxiety, Stress and Coping, 16(2): 195-211.

35 MOODIE, G. (2003) "Education is the missing link", Sunday Times Business Times, 30 March: 9.

36 NEUMAN, W.L. (2004) Basics of Social Research: Qualitative and Quantitative Approaches, Pearson/ Allyn \& Bacon: Boston.

37 NSIDI, T. (2002) News editor, Sunday Tribune, Personal interview with the research team for the purposes of the South African National Editors Forum National Journalism Skills Audit at the office of the Sunday Tribune on 15 March 2002, Copy of the notes available from the first author.

38 OOSTHUIZEN, T.F.J.; DE BRUYN, H.E.C.; JACOBS, H. \& KRUGER, S. (eds.) (2002) Management Tasks for Managerial Success, Entrepro: Johannesburg.

39 PETERS, S.L. (2004) "Managing newsroom employees: A guide to solving common personnel problems", http://www.mediamanagementcenter. org/center/web/publications/data/Managing.pdf, (Accessed 21 June 2004.)

40 RANKIN, W.P. (1986) The Practice of Newspaper Management, Praeger: New York.

41 RENSBURG, R. \& CANT, M. (eds.) (2003) Public Relations: South African Perspectives, Heinemann: Sandown.

42 RUE, L.W. \& BYARS, L.L. (2000) Management: Skills and Application, Irwin McGraw-Hill: Boston.

43 SAS INSTITUTE. (1999) SAS/STAT Procedure Guide, Version 6, Third Edition, Volume 2, SAS Institute: Cary.

44 SOUTH AFRICA (1996) National Small Business Act, 102 of 1996, Government Printer: Pretoria.

45 SOUTH AFRICA (2003) National Small Business Amendment Act, 26 of 2003, Government Printer: Pretoria.

46 SOUTH AFRICA YEARBOOK (2000/01) http:// www.gcis.gov.za/docs/publications/yearbook.htm. (Accessed 7 September 2005.) 
47 SOUTH AFRICA YEARBOOK (2004/05) http:// www.gcis.gov.za/docs/publications/yearbook.htm. (Accessed 7 September 2005.)

48 STEYN, E. \& DE BEER, A.S. (2002) South African National Editors Forum 2002 National Journalism Skills Audit Final Report, http://www. scribe.co.za. (Accessed).

49 STEYN, E.F. \& DE BEER A.S. (2003) "Preparing for the future: The level of journalism skills in South African media - A reason for concern?" Paper read at the International Communication Division of the Association for Education in Journalism and Mass Communication 86th Annual Convention, Kansas City, 30 July-2 August.

50 STEYN, E.F. \& DE BEER, A.S. (2004) “The level of journalism skills in South African media: A reason for concern in a developing democracy?" Journalism Studies, 5(3): 387-397.

51 STEYN, E., DE BEER, A.S. \& STEYN, T.F.J. (2005a) "South African national editors forum national journalism skills audit phase 2: Managerial competencies among first-line news managers in South Africa's mainstream media newsrooms", final report, http://www.sanef.org.za. (accessed).

52 STEYN, E.; DE BEER, A.S. \& STEYN, D. (2005b) 'Obtaining 'better news' through better internal news management: A survey of first-line managerial competencies in South Africa", Ecquid Novi, 26(2): 212-227.
53 STEYN, E. \& STEYN, T.F.J. (2003) "Managerial competencies required in the media newsroom: an exploratory study", Paper read at the 'Media in Africa: current issues, future challenges conference', Stellenbosch, 11-12 September.

54 STRUWIG, F.W. \& STEAD, G.B. (2001) Planning, Designing and Reporting Research, Pearson Education South Africa: Cape Town.

55 THOMPSON, T.A. (2001). "Insight for managers", in Graham, G. \& Thompson, T. (eds.) Inside Newsroom Teams: An Editor's Guide to the Promise and Problems, Media Management Center: Evanston, IL.

56 UNDERWOOD, D. (1995) When MBAs Rule the Newsroom: How the Marketers and Managers are Reshaping Today's Media, Columbia University Press: New York.

57 VENTER, E.; VAN EEDEN, S.; KING, T. \& SHARP, G. (2004) "An investigation into the managerial competencies required for small business success," Paper read at the 49th International Council for Small Business Conference, Johannesburg, 21-23 June.

58 VISAGIE, J.C. (1997) "SMMEs' challenges in reconstructing South Africa", Management Decision, 35(9): 660-667.

59 WRIGHT, C. (1995) Successful Small Business Management in South Africa, Zebra: Sandton. 